\title{
Soil properties and herbaceous characteristics in an age sequence of Haloxylon ammodendron plantations in an oasis-desert ecotone of northwestern China
}

\author{
ZHANG Ke ${ }^{1,2}$, SU Yongzhong ${ }^{1 *}$, WANG Ting ${ }^{1,2}$, LIU Tingna ${ }^{1}$ \\ ${ }^{1}$ Linze Inland River Basin Research Station, Cold and Arid Regions Environmental and Engineering Research Institute, Chinese \\ Academy of Sciences, Lanzhou 730000, China; \\ ${ }^{2}$ University of Chinese Academy of Sciences, Beijing 100049, China
}

\begin{abstract}
Haloxylon ammodendron, a typical desert shrub with C4 pathway of photosynthesis, possessing a strong ability to adapt to an extreme drought environment, has a rapid growth rate in sandy lands and is widely used in sand-fixing shelter-forest systems in oasis-desert ecotones. To assess the effects of $H$. ammodendron plantation on the soil, we measured soil properties and herbaceous characteristics along a nearly 40-year chronosequence after $\mathrm{H}$. ammodendron was planted in shifting sand dunes in an oasis-desert ecotone. Results showed that silt and clay fractions increased significantly in the topsoil. The accumulation rates of soil organic carbon (SOC), total nitrogen (TN) and total phosphorus (TP) were faster in the early stages (0-9 years) and slower in the late stages (9-39 years). The soil pH and electrical conductivity (EC) were higher than those in the non-vegetation dunes. Moreover, the soil properties in the topsoil $(0-5 \mathrm{~cm})$ showed larger variation scope than those in the deeper soil layers $(5-20 \mathrm{~cm})$. The significant relationships of the soil silt+clay content with the chemical properties mainly appeared in the topsoil. The wind erosion susceptibility of the soil, evaluated by erodible fraction (EF), decreased significantly with increasing $H$. ammodendron plantation age. Additionally, the annual pioneer herb, Agriophyllum squarrosum, was gradually substituted by the annual salt-tolerant herb, Bassia dasyphylla, with increasing plantation age. These results showed beneficial effects of $H$. ammodendron plantation on improving soil conditions. However, the dynamics of the herbaceous species also reminded us that the longterm effects of $H$. ammodendron plantation, especially on changes in vegetation composition, still need further evaluation.
\end{abstract}

Keywords: Haloxylon ammodendron; soil properties; herbaceous; erodible fraction; oasis-desert ecotone

Citation: ZHANG Ke, SU Yongzhong, WANG Ting, LIU Tingna. 2016. Soil properties and herbaceous characteristics in an age sequence of Haloxylon ammodendron plantations in an oasis-desert ecotone of northwestern China. Journal of Arid Land, 8(6): 960-972. doi: 10.1007/s40333-016-0096-6

In arid regions, oasis only account for a very small portion (4\%) of the land surface but they are important for nourishing more than $95 \%$ of the population and maintaining more than $90 \%$ of social wealth (Han, 1999; Su et al., 2007). However, due to the anthropogenic overexploitation and irrational use of water and soil resources, the desertification around oasis has become a major obstacle for the sustainable development of oasis in the arid regions of Northwest China (Han, 1999; Pan, 2001; Su et al., 2007, 2012). Moreover, wind erosion, which is a widespread cause of serious soil degradation in arid and semi-arid regions, facilitates the development of desertification

*Corresponding author: SU Yongzhong (E-mail: suyzh@1zb.ac.cn)

Received 2015-11-09; revised 2016-04-22; accepted 2016-05-26

(C) Xinjiang Institute of Ecology and Geography, Chinese Academy of Sciences, Science Press and Springer-Verlag Berlin Heidelberg 2016 
and poses a serious threat to the cropping agriculture in oasis regions (Borrelli et al., 2014). Consequently, controlling the further development of desertification and reducing its negative effects on oasis are of pivotal importance.

One typical and successful case for oasis restoration and desertified land reclamation is performed in the middle of the Hexi Corridor in northwestern China (Pan and Chao, 2003; Su et al., 2007; Zhao et al., 2008). In 1975, Linze Inland River Basin Research Station was established in an oasis-desert ecotone to conduct a desertification control project through monitoring the desertification processes and to develop effective techniques to restore vegetation and rehabilitate desertified land. H. ammodendron was selected by the project as a main restoration species due to its drought-tolerant ability and faster growth rate (Su et al., 2007). H. ammodendron was arranged in belts (row spacing, 1.5-2 m; neighboring plant seedling spacing, $1 \mathrm{~m}$ ) and the orientation of the belts was perpendicular to local prevailing wind direction. To date, the H. ammodendron plantation has formed an age sequence protection system in the study area (Su et al., 2007).

Through assessing the effects of long-term revegetation on soil restoration, this study found that there was a continuous increase in the silt and clay contents in the surface soils with increasing plantation age. As a result, increased soil fine particles improved both the soil nutrients and soil water-holding capacity, and further created a favorable environment for the forbs and grasses ( $\mathrm{Su}$ and Zhao, 2003; Li et al., 2007; Zhao et al., 2007). These positive effects played pivotal roles in preventing the desertification processes. However, the main concerns of previous studies on $H$. ammodendron focused on the photosynthetic characteristics or the soil moisture distribution and a few of them investigated the soil changes following the establishment of $H$. ammodendron plantations (He and Zhao, 2004; Su et al., 2007; Zhu and Jia, 2011). It is still unclear what effects that $H$. ammodendron have on the soil properties and whether the improved soil environment could provide a favorable condition for the successful establishment of herbaceous species. A better understanding of these questions is critical to evaluate the soil restoration status in the oasis-desert ecotone over the long-term restoration.

In present study, we investigated the long-term effects of $H$. ammodendron plantations on the soil properties and herbaceous characteristics. Our particular objectives were to (1) determine the variations of the soil physical and chemical properties; (2) assess the long-term effects of $H$. ammodendron plantations on soil restoration; and (3) examine the results of herbaceous species establishment with increasing plantation age.

\section{Materials and methods}

\subsection{Study area}

The study was carried out at the Linze Inland River Basin Research Station, Chinese Academy of Sciences $\left(39^{\circ} 22^{\prime} 48^{\prime \prime} \mathrm{N}, 100^{\circ} 7^{\prime} 12^{\prime \prime} \mathrm{E}\right)$. The station is located at the southwest fringe of the Badain Jaran Desert with the elevation ranged from 1,378 to 1,391 $\mathrm{m}$. The typical temperate desert climate here is dry and hot in summer and cold in winter, with plenty of sunshine, very little precipitation and strong winds. The annual mean temperature is $7.6^{\circ} \mathrm{C}$. The mean annual precipitation is 117 $\mathrm{mm}$. The annual mean wind velocity is $3.2 \mathrm{~m} / \mathrm{s}$ and the prevailing wind direction is northwest. Gales with a velocity $>17 \mathrm{~m} / \mathrm{s}$ occurs 15 or more days a year ( $\mathrm{Su}$ et al., 2007). The main soil types are aripsamment and calciorthids, which have a loose texture, a very low organic matter and are very susceptible to wind erosion (Chen et al., 1998; Su et al., 2007). The desert shrubs are the main components of the natural vegetation at the edge of the oasis, including Calligonum mongolicum, Calligonum gobicum, H. ammodendron, Caragana korshinskii, Hedysarum scoparium and Tamarix chinensis (Su et al., 2010).

\subsection{Methods}

The experiment sites were selected at the northeast of the Linze Inland River Basin Research Station (Fig. 1). We adopted a space-for-time substitute method to study the dynamics of the soil properties and the development of the herbaceous species in an age sequence of 2-, 5-, 9-, 13-, 16-, 31 - and 39-year after the H. ammodendron was planted on the shifting sand dunes. The initial soil 
properties of the sand dunes were assumed similar to each other ( $\mathrm{Su}$ et al., 2002; $\mathrm{Su}$ and $\mathrm{Zhao}$, 2003). Within each plantation age, three shrub plots, $10 \mathrm{~m} \times 10 \mathrm{~m}$ each, were randomly selected. Additionally, three non-vegetated dunes in the vicinity of the planted sites were chosen as controls (age 0 ) for the chronosequence. The distribution of the sample plots are shown in Fig. 1.

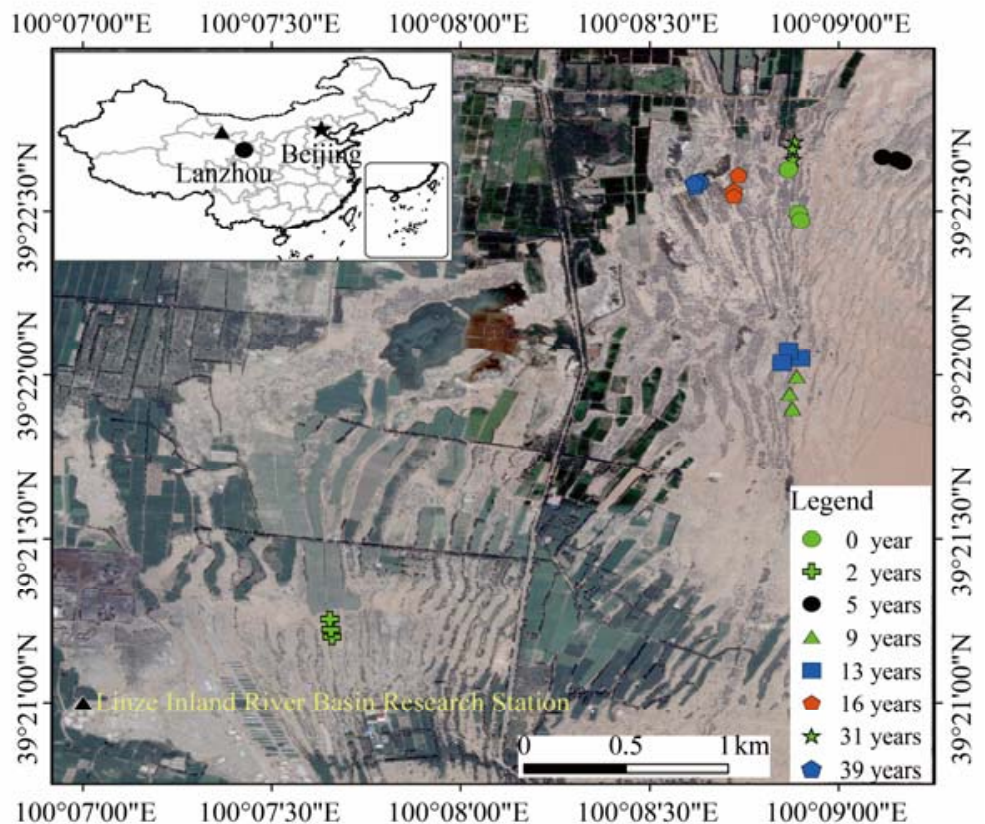

Fig. 1 The location of the sampling plots

Vegetation investigation and soil sampling were carried out from 29 July to 3 August 2014. In each plantation age, five similar H. ammodendron individuals were selected as measuring objects in each plot and their growth points were chosen as soil sampling points. The growth characteristics of $H$. ammodendron under each age are presented in Table 1 . Meanwhile, three $1 \mathrm{~m} \times 1 \mathrm{~m}$ herb quadrates were randomly established in each plot to investigate the composition of the herbaceous species with the number and the heights of the individuals measured.

Table 1 Morphological characteristics of Haloxylon ammodendron in age an sequence of 2-, 5-, 9-, 13-, 16-, 31and 39-year in an oasis-desert ecotone, northwestern China

\begin{tabular}{cccccc}
\hline $\begin{array}{c}\text { Age sequence } \\
(\text { year })\end{array}$ & $\begin{array}{c}\text { Shrub height } \\
(\mathrm{m})\end{array}$ & $\begin{array}{c}\text { Stem diameter } \\
(\mathrm{m})\end{array}$ & $\begin{array}{c}\text { Crown area } \\
\left(\mathrm{m}^{2}\right)\end{array}$ & $\begin{array}{c}\text { Existing living density } \\
(\%)\end{array}$ & $\begin{array}{c}\text { Dead branches } \\
(\%)\end{array}$ \\
\hline 2 & $0.59 \pm 0.06^{\mathrm{d}}$ & $0.97 \pm 0.06^{\mathrm{d}}$ & $0.28 \pm 0.07^{\mathrm{d}}$ & $89.91 \pm 10.19^{\mathrm{d}}$ & - \\
5 & $2.02 \pm 0.16^{\mathrm{c}}$ & $5.10 \pm 0.70^{\mathrm{c}}$ & $3.02 \pm 0.72^{\mathrm{c}}$ & $60.00 \pm 0.00^{\mathrm{b}}$ & $3.33 \pm 0.88^{\mathrm{d}}$ \\
9 & $3.19 \pm 0.18^{\mathrm{b}}$ & $8.45 \pm 0.89^{\mathrm{b}}$ & $6.78 \pm 1.50^{\mathrm{b}}$ & $41.67 \pm 1.92^{\mathrm{bc}}$ & $10.67 \pm 0.88^{\mathrm{c}}$ \\
13 & $3.41 \pm 0.16^{\mathrm{b}}$ & $9.85 \pm 0.32^{\mathrm{ab}}$ & $10.48 \pm 1.46^{\mathrm{ab}}$ & $29.44 \pm 3.09^{\mathrm{c}}$ & $12.33 \pm 2.60^{\mathrm{c}}$ \\
16 & $3.75 \pm 0.21^{\mathrm{b}}$ & $9.94 \pm 1.32^{\mathrm{ab}}$ & $11.31 \pm 0.64^{\mathrm{ab}}$ & $27.78 \pm 4.01^{\mathrm{c}}$ & $15.67 \pm 0.67^{\mathrm{c}}$ \\
31 & $3.93 \pm 0.34^{\mathrm{b}}$ & $10.17 \pm 1.35^{\mathrm{ab}}$ & $12.02 \pm 0.8^{\mathrm{ab}}$ & $28.89 \pm 3.89^{\mathrm{c}}$ & $23.33 \pm 2.60^{\mathrm{b}}$ \\
39 & $4.78 \pm 0.36^{\mathrm{a}}$ & $12.99 \pm 0.22^{\mathrm{a}}$ & $20.20 \pm 2.98^{\mathrm{a}}$ & $9.44 \pm 2.00^{\mathrm{dc}}$ & $42.67 \pm 1.33^{\mathrm{a}}$ \\
$d f$ & 20 & 20 & 20 & 20 & 17 \\
$F$ & 35.42 & 22.11 & 65.95 & 31.75 & 82.19 \\
$P$ & $<0.001$ & $<0.001$ & $<0.001$ & $<0.001$ & $<$ \\
Error type & $\mathrm{I}$ & $\mathrm{I}$ & $\mathrm{I}$ & $\mathrm{I}$ & $\mathrm{I}$ \\
\hline
\end{tabular}

Note: Crown area $=\pi \times\left(D_{1} / 2 \times D_{2} / 2\right)$, where $D_{1}$ and $D_{2}$ represent the east-west direction and the north-sounth direction, respectively; Mean \pm SE. Different letters in the column mean significant differeces at $P=0.05$ level; $d f$, degree of freedom; $F$, F-statistic value; $P$, significant level; I: type one error. 


\subsection{Soil sampling and analysis}

For each individual H. ammodendron, soil samples were collected from two locations: under shrub canopy and in the alley. In each plot, soil samples at the depths of 0-5 and 5-20 cm were collected from five sampling points, and then the 5 samples at the same depth were mixed into one sample. The soil sample collected under shrub canopy was taken at the position as close to the center of the H.ammodendron as possible. The samples from the alley was taken in the middle of each H.ammodendron belt. At the control site (age 0), samples were collected from the chosen sites as described in Methods.

Soil samples were air-dried first and then passed through a 2-mm sieve. A size analysis was carried out using the pipette method (Gee and Bauder, 1986). The soil $\mathrm{pH}$ and electrical conductivity (EC) were measured in a soil-water suspension (1:1 and 1:5 soil-water ratio, respectively) by Multiline F/SET-3, a measuring instrument produced by WTW, Germany. Part of the air-dried and sieved samples were further crushed and passed through a $0.1-\mathrm{mm}$ sieve to analysis soil organic carbon (SOC), total carbon (TC), total nitrogen (TN), total phosphorus (TP) and the available phosphorus (P). SOC was determined by the potassium dichromate volumetric method with external heating (GB7857-1987, 1988). TC and TN were measured using a vario MACRO CUBE manufactured by Elementar Analysensysteme, Germany. The soil TP was measured by colorimetry after $\mathrm{H}_{2} \mathrm{SO}_{4}-\mathrm{H}_{2} \mathrm{O}_{2}$ digestion. The available $\mathrm{P}$ was also measured using colorimetry after extracting by $\mathrm{NaHCO}_{3}$. The calculation of the $\mathrm{CaCO}_{3}$ content was derived from the inorganic carbon, which was derived by subtracting the SOC content from the TC content. The equation is $\mathrm{CaCO}_{3}(\mathrm{mg} / \mathrm{g})=(\mathrm{TC}-\mathrm{SOC}) \times 8.33(\mathrm{Bao}, 2000)$.

\subsection{Computation of erodible fraction (EF)}

Based on the soil physical and chemical properties, the soil erodible fraction (EF) was computed by the multiple regression equation (Eq. 1) proposed by Fryrear et al. (1994).

$$
E F=\frac{0.29+0.31 S_{a}+0.17 S_{i}+0.33 S_{c}-2.59 O M-0.95 \mathrm{CaCO}_{3}}{100} .
$$

Where $S_{a}$ is the soil sand content, $S_{i}$ is the soil silt content, $S_{c}$ is the ratio of sand to clay content and $O M$ is the organic matter content. All of the variables were expressed in \% (Fryrear et al., 1994; Borrelli, 2014).

Fryrear et al. (1994) suggested that Eq. 1 has restrictions and it must be tested for soils different from US soils. López et al. (2007) found that Eq. 1 is not useful for predicting EF in Spanish soil with high $\mathrm{CaCO}_{3}$ content and Argentinean soil with the low sand/clay ratio and high organic matter contents. Novertheless, Eq. 1 was adopted by Borrelli et al. (2014) with 19,967 samples of European soils. Thus, Eq. 1 became one of the most robust and widely tested equations defined in the literature to assess the intrinsic susceptibility of soil to wind erosion. Accordingly, we also chose Eq. 1 to calculate the soil erodible fraction and to delineate the susceptibility of the $H$. ammodendron soils to wind erosion in time patterns.

\subsection{Data analyses}

To confirm the differences of the soil properties under canopy (A) and in the alley (B), an enrichment ratio $(\mathrm{E})=\mathrm{A} / \mathrm{B}$ was adopted (Wezel et al., 2000; Su and Zhao, 2003). E $>1$ indicates a higher nutrition concentration under canopy. The value of $\mathrm{E}$ reflects the facilitation of $H$. ammodendron plantation with plantation ages on the spatial distribution of soil properties.

Comparisons of the soil properties among plantation ages were restricted by the location and the depth. A variance analysis, Student-Newman-Keuls test, compared the morphological traits of $H$. ammodendron, the variation of soil $\mathrm{C}: \mathrm{N}: \mathrm{P}$, the soil $\mathrm{CaCO}_{3}$ :available $\mathrm{P}$ ratios, the $\mathrm{pH}, \mathrm{EC}$ values and the E value among platation ages, respectively. All of these variables of each plantation age were constituted by data from three plots. In each plot, the morphological traits data, except for the dead branches, were derived from an average of five individual points. All of the data satisfied the restrictions of homogeneity of variance $(P>0.05)$. To test each variable differences among the plantation ages, the null hypothesis $\left(\mathrm{H}_{0}\right)$ was defined as no significant difference. If the significant 
level $(P)$ of the $F$-statistic was less than the significance level $(P=0.05)$, it denoted that $\mathrm{H}_{0}$ was rejected (type $\mathrm{I}$ error) and $\mathrm{H}_{0}$ was accepted error (type II error) if $P$ value was larger than the significance level. Regression analyses were used to explore the relationships of the SOC, TN, TP, and $E F$ with the plantation ages and the relationship between silt+clay content and the soil chemical properties. All of the analyses were conducted using SPSS 18.0 (IBM, Chicago, IL, USA) and Origin 8.5 (Origin Lab, Northampton, MA, USA).

\section{Results}

\subsection{Changes in soil properties along a 40 -year chronosequence}

\subsubsection{Soil physical properties}

Soil physical properties clearly showed improved trends in the soil texture with the plantation ages (Fig. 2). Compared with the age 0 , in age 39 at the depth of $0-5 \mathrm{~cm}$, sand content significantly decreased by $11.9 \%$ under canopy and by $9.6 \%$ in the alley; the silt content increased significantly by $290.6 \%$ under canopy and by $193.6 \%$ in the alley; the clay content increased by $181.1 \%$ under canopy and by $183.9 \%$ in the alley (Figs. 2a, c). At the depth of 5-20 cm, the effects of $H$. ammodendron plantation on the soil physical properties were less marked. The sand content still decreased and the silt content increased, even though there were no significant difference in the clay contents among plantation ages (Figs. 2b, d).

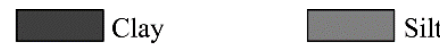

Silt $\quad$ Sand

(a) Under canopy $(0-5 \mathrm{~cm})$

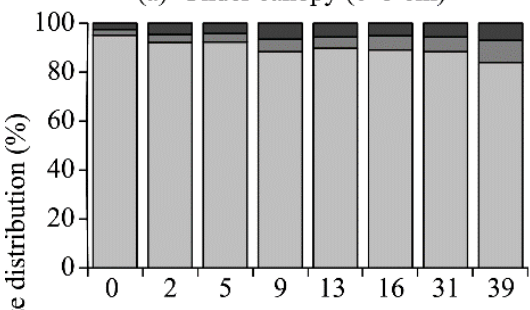

(b) Under canopy $(5-20 \mathrm{~cm})$

(c) Alley $(0-5 \mathrm{~cm})$
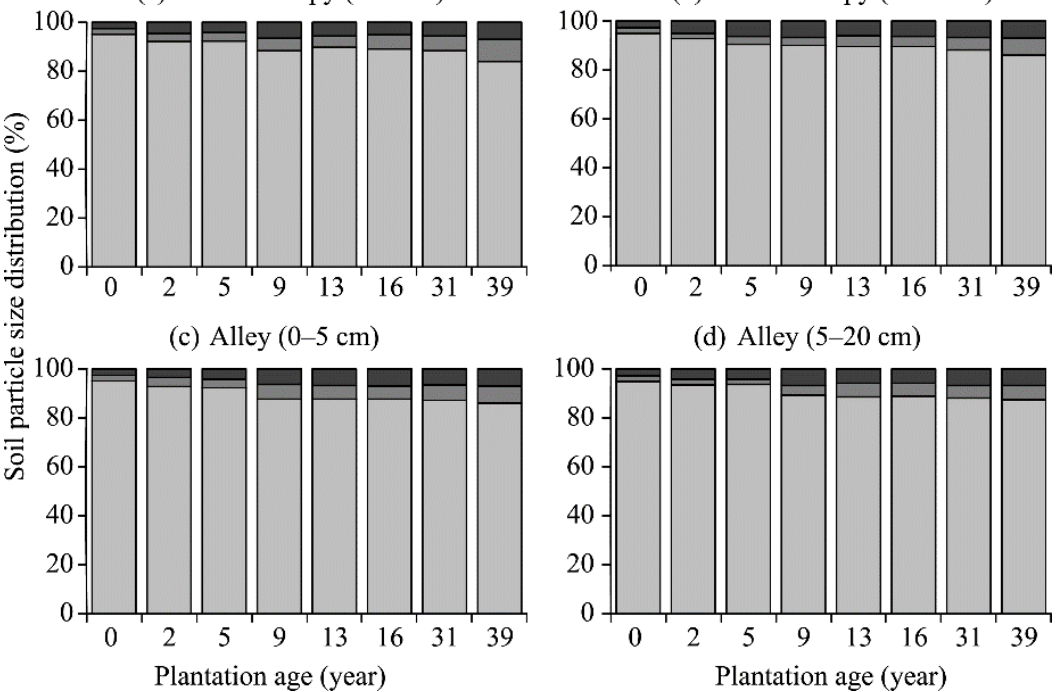

(d) Alley $(5-20 \mathrm{~cm})$

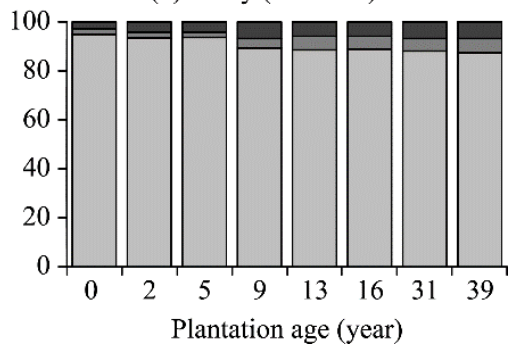

Fig. 2 Stacked column of soil physical properties (sand, silt, and clay) at different locations and depths along the plantation age sequence

\subsubsection{Soil chemical properties}

The $H$. ammodendron plantation contributed to the enrichment of the SOC, TN, and $\mathrm{TP}$ in the desertified land (Fig. 3). The SOC and TN accumulation, both under canopy and in the alley, increased significantly with the plantation ages. Furthermore, the increase at $0-5 \mathrm{~cm}$ depth was faster than those at 5-20 cm depth (Figs. 3a-h). In contrast, TP only showed a significant increase at $0-5 \mathrm{~cm}$ depth (Figs. $3 \mathrm{i}, \mathrm{k}$ ).

The C:N ratios at $0-5$ and 5-20 $\mathrm{cm}$ depths in all of the plantation ages were not significantly different under canopy or in the alley (Figs. 4a-d). Compared with age 0 , the $\mathrm{C}: \mathrm{P}$ and $\mathrm{N}: \mathrm{P}$ ratios increased significantly at $0-5 \mathrm{~cm}$ depth, with a 6.4- and 4.3-fold increase for C:P and a 6.6- and 5.8-fold increase for N:P under canopy and in the alley in age 39, respectively (Figs. 4e, g, i, k). Nevertheless, the C:P and N:P ratios at 5-20 $\mathrm{cm}$ depth under all plantation ages showed relatively 
narrow variations (Figs. 4f, $h, j, 1)$.

The soil $\mathrm{pH}$ was not varied significantly after 9 years of plantation, either under canopy or in the alley (Figs. 5a-d). The soil EC increased from 115.40 to $1,996.17 \mu \mathrm{s} / \mathrm{cm}$ at $0-5 \mathrm{~cm}$ depth under canopy, from 115.40 to $908.00 \mu \mathrm{s} / \mathrm{cm}$ at $0-5 \mathrm{~cm}$ depth in the alley, from 157.13 to $1,456.33 \mu \mathrm{s} / \mathrm{cm}$ at 5-20 cm depth under canopy and from 157.13 to $1,694.67 \mu \mathrm{s} / \mathrm{cm}$ at $5-20 \mathrm{~cm}$ depth in the alley (Figs. 5e-h).

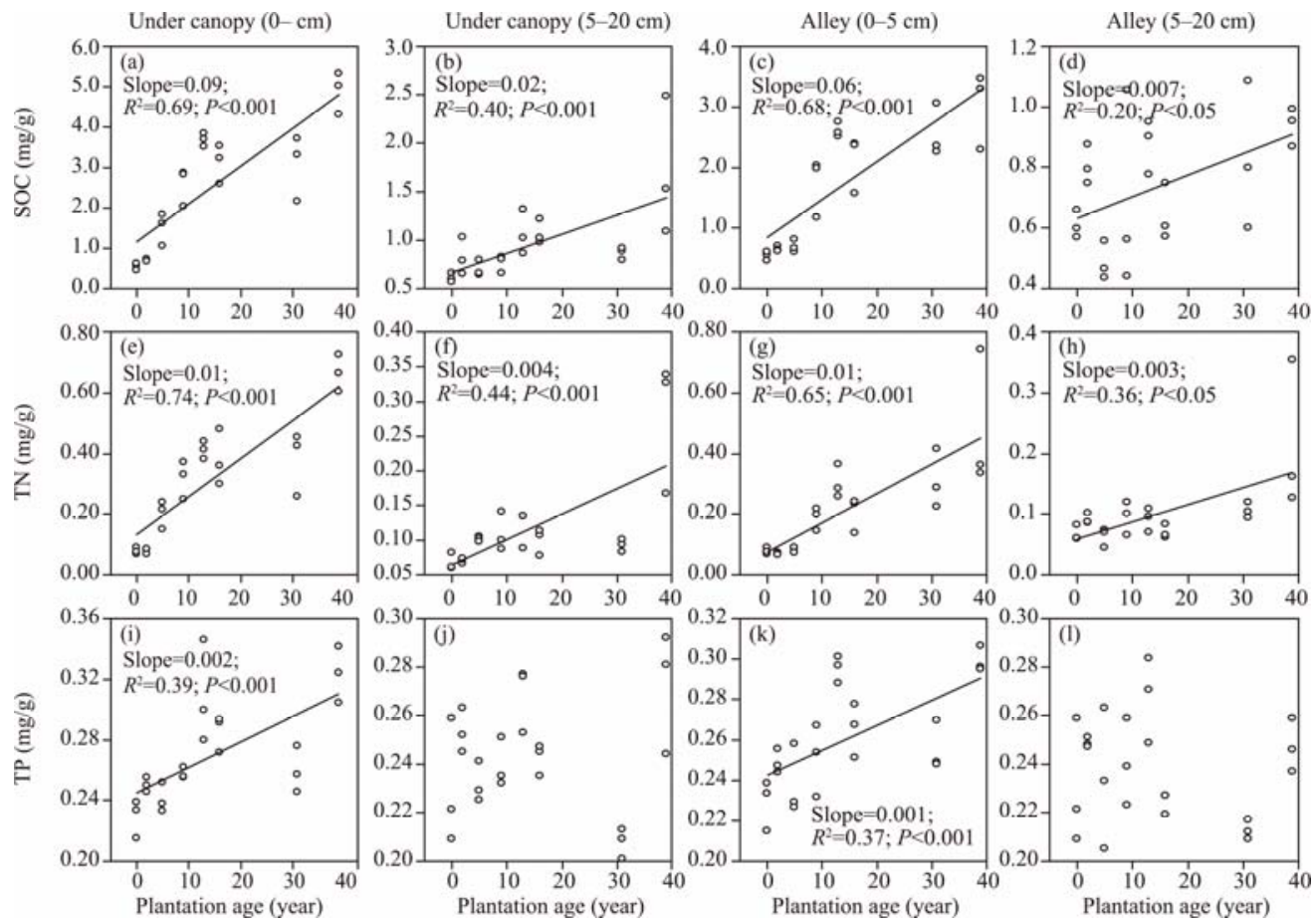

Fig. 3 Concentration dynamics of soil organic carbon (SOC), total nitrogen (TN) and total phosphorus (TP) at different locations and depths along the plantation age sequence

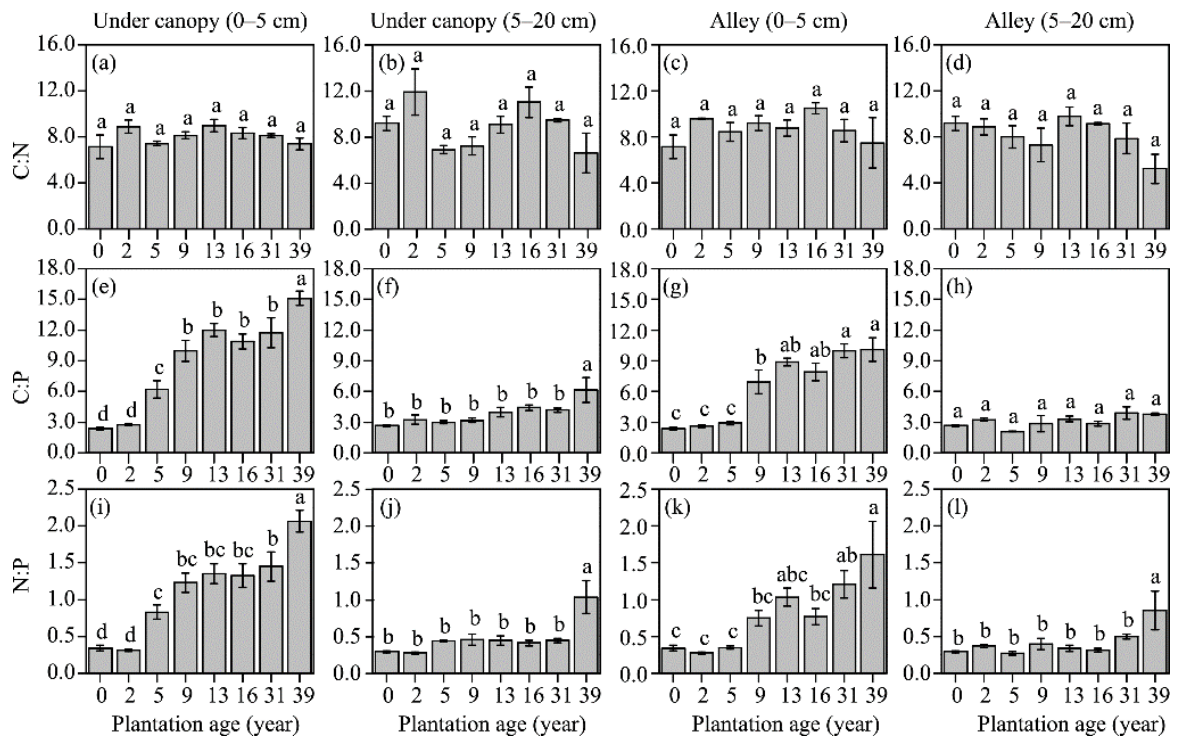

Fig. 4 Variations of soil C:N:P ratios at different locations and depths along the plantation age sequence; Bars mean standard errors. Letters above each column chart mean significance at $P=0.05$ level. 

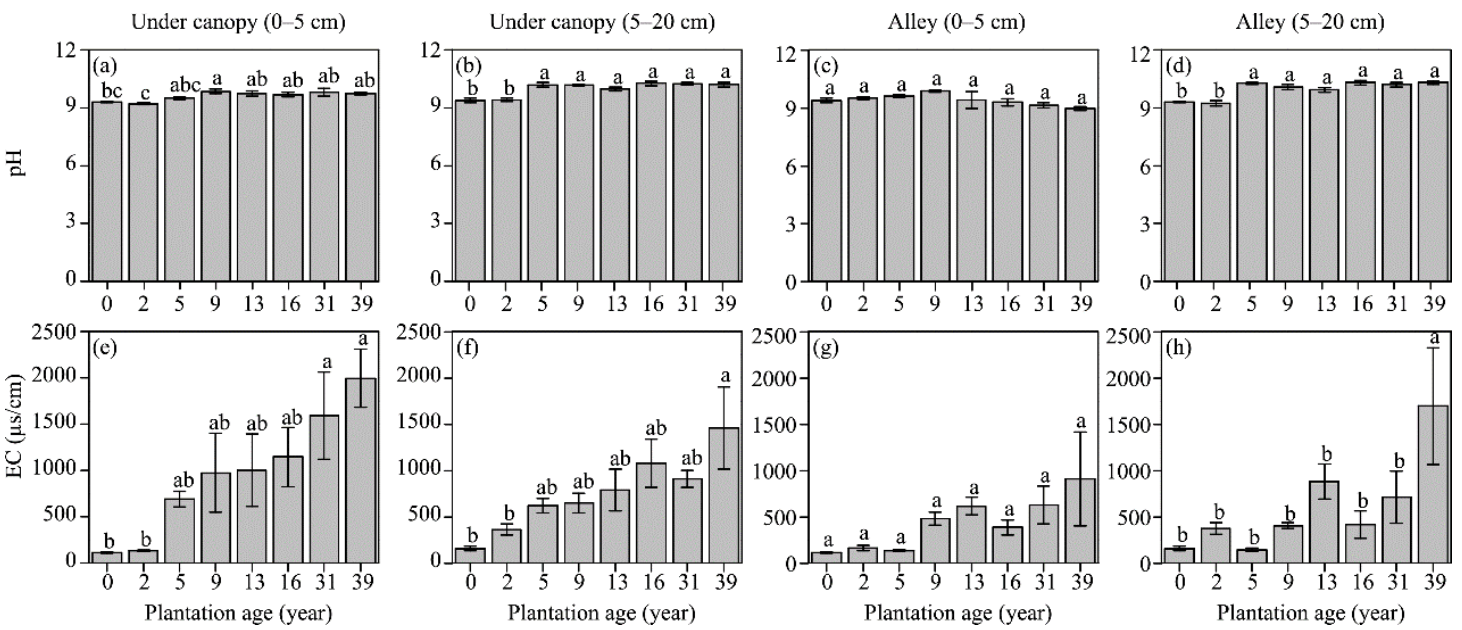

Fig. 5 Soil $\mathrm{pH}$ and electrical conductivity (EC) at soil depth of $0-5$ and 5-20 $\mathrm{cm}$ at different locations along the plantation age sequence; Bars mean standard errors. Letters above each column chart mean significance at $P=0.05$ level.

With increasing plantation age, a significant increase in the soil available $\mathrm{P}$ occurred only at the topsoil $(0-5 \mathrm{~cm})$ under canopy (Fig. 6a). The $\mathrm{CaCO}_{3}$ contents among plantation ages were not significantly different. A sharp decline in the $\mathrm{CaCO}_{3}$ :available $\mathrm{P}$ ratio only occurred at the $0-5 \mathrm{~cm}$ depth under canopy (Fig. 6e).

Most of the soil properties showed significant differences between the locations beneath the $H$. ammodendron canopy and in the alley (Fig. 2-7). Nevertheless, the enrichment ratio (E) was not significantly different for a majority of soil properties among plantation ages (Table 2).
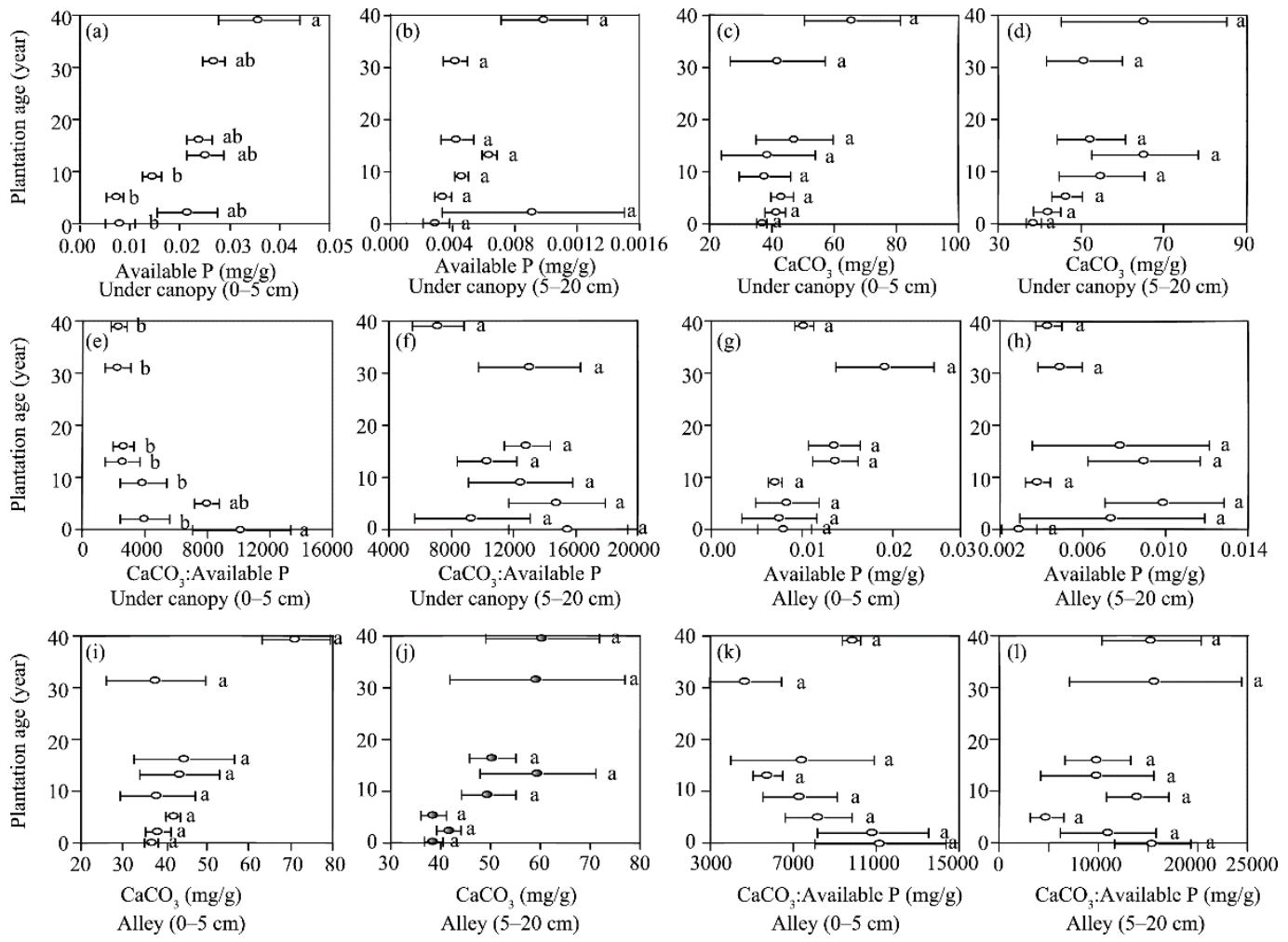

Fig. 6 Variations of available $\mathrm{P}, \mathrm{CaCO}_{3}$, and their ratios at different locations and depths along the plantation age sequence; Bars mean standard errors. Letters above each column chart mean significance at $P=0.05$ level. 

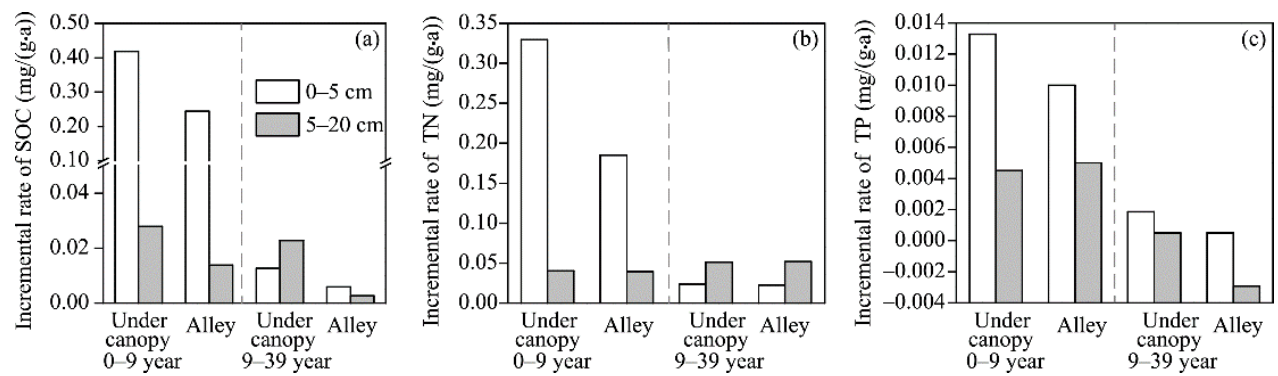

Fig. 7 Accumulation of SOC, TN and TP at two growth stages (0-9 and 9-39 years) at different locations after H. ammodendron was planted

Table 2 Enrichment ratio (E) of soil chemical properties along the age sequence

\begin{tabular}{|c|c|c|c|c|c|c|c|c|c|c|c|c|}
\hline \multirow{2}{*}{ Variable } & \multirow{2}{*}{$\begin{array}{l}\text { Depth } \\
(\mathrm{cm})\end{array}$} & \multicolumn{7}{|c|}{ Plantation age (year) } & \multirow{2}{*}{$d f$} & \multirow{2}{*}{$F$} & \multirow{2}{*}{$P$} & \multirow{2}{*}{$\begin{array}{l}\text { Error } \\
\text { type }\end{array}$} \\
\hline & & 2 & 5 & 9 & 13 & 16 & 31 & 39 & & & & \\
\hline \multirow[t]{2}{*}{$\mathrm{SOC}$} & $0-5$ & $1.05^{\mathrm{a}}$ & $2.17^{\mathrm{a}}$ & $1.62^{\mathrm{a}}$ & $1.41^{\mathrm{a}}$ & $1.50^{\mathrm{a}}$ & $1.25^{\mathrm{a}}$ & $1.70^{\mathrm{a}}$ & 20 & 1.93 & $>0.05$ & II \\
\hline & $5-20$ & $1.02^{\mathrm{a}}$ & $1.44^{\mathrm{a}}$ & $1.27^{\mathrm{a}}$ & $1.25^{\mathrm{a}}$ & $1.70^{\mathrm{a}}$ & $1.11^{\mathrm{a}}$ & $1.82^{\mathrm{a}}$ & 20 & 1.38 & $>0.05$ & II \\
\hline \multirow[t]{2}{*}{$\mathrm{TN}$} & $0-5$ & $1.15^{\mathrm{b}}$ & $2.40^{\mathrm{a}}$ & $1.75^{\mathrm{ab}}$ & $1.38^{\mathrm{ab}}$ & $1.91^{\mathrm{ab}}$ & $1.37^{\mathrm{ab}}$ & $1.53^{\mathrm{ab}}$ & 20 & 2.92 & $<0.05$ & I \\
\hline & $5-20$ & $0.77^{\mathrm{a}}$ & $1.69^{\mathrm{a}}$ & $1.17^{\mathrm{a}}$ & $1.36^{\mathrm{a}}$ & $1.47^{\mathrm{a}}$ & $0.88^{\mathrm{a}}$ & $1.43^{\mathrm{a}}$ & 20 & 2.211 & $>0.05$ & II \\
\hline \multirow[t]{2}{*}{ TP } & $0-5$ & $1.01^{\mathrm{a}}$ & $1.01^{\mathrm{a}}$ & $1.03^{\mathrm{a}}$ & $1.04^{\mathrm{a}}$ & $1.08^{\mathrm{a}}$ & $1.02^{\mathrm{a}}$ & $1.08^{\mathrm{a}}$ & 20 & 0.49 & $>0.05$ & II \\
\hline & $5-20$ & $1.02^{\mathrm{a}}$ & $0.10^{\mathrm{a}}$ & $1.00^{\mathrm{a}}$ & $1.01^{\mathrm{a}}$ & $1.08^{\mathrm{a}}$ & $0.98^{\mathrm{a}}$ & $1.10^{\mathrm{a}}$ & 20 & 0.94 & $>0.05$ & II \\
\hline \multirow{2}{*}{$\begin{array}{l}\text { Available } \\
\text { P }\end{array}$} & $0-5$ & $3.89^{\mathrm{a}}$ & $1.10^{\mathrm{a}}$ & $2.09^{\mathrm{a}}$ & $1.85^{\mathrm{a}}$ & $1.95^{\mathrm{a}}$ & $1.67^{\mathrm{a}}$ & $3.43^{\mathrm{a}}$ & 20 & 2.60 & $>0.05$ & II \\
\hline & $5-20$ & $2.51^{\mathrm{a}}$ & $0.50^{\mathrm{a}}$ & $1.24^{\mathrm{a}}$ & $0.92^{\mathrm{a}}$ & $0.77^{\mathrm{a}}$ & $0.91^{\mathrm{a}}$ & $2.45^{\mathrm{a}}$ & 20 & 1.123 & $>0.05$ & II \\
\hline \multirow[t]{2}{*}{$\mathrm{CaCO}_{3}$} & $0-5$ & $1.09^{\mathrm{a}}$ & $1.03^{\mathrm{a}}$ & $1.01^{\mathrm{a}}$ & $0.83^{\mathrm{a}}$ & $1.07^{\mathrm{a}}$ & $1.11^{\mathrm{a}}$ & $0.91^{\mathrm{a}}$ & 20 & 0.61 & $>0.05$ & II \\
\hline & $5-20$ & $1.01^{\mathrm{a}}$ & $1.21^{\mathrm{a}}$ & $1.11^{\mathrm{a}}$ & $1.10^{\mathrm{a}}$ & $1.03^{\mathrm{a}}$ & $0.95^{\mathrm{a}}$ & $1.04^{\mathrm{a}}$ & 20 & 0.89 & $>0.05$ & II \\
\hline \multirow[t]{2}{*}{$\mathrm{pH}$} & $0-5$ & $1.00^{\mathrm{a}}$ & $1.08^{\mathrm{a}}$ & $1.02^{\mathrm{a}}$ & $1.02^{\mathrm{a}}$ & $1.06^{\mathrm{a}}$ & $1.04^{\mathrm{a}}$ & $1.06^{\mathrm{a}}$ & 20 & 2.7 & $>0.05$ & II \\
\hline & $5-20$ & $0.99^{\mathrm{c}}$ & $1.06^{\mathrm{bc}}$ & $1.03^{\mathrm{abc}}$ & $1.06^{\mathrm{abc}}$ & $1.11^{\mathrm{ab}}$ & $1.12^{\mathrm{a}}$ & $1.14^{\mathrm{a}}$ & 20 & 7.29 & 0.001 & I \\
\hline \multirow[t]{2}{*}{$\mathrm{EC}$} & $0-5$ & $0.88^{\mathrm{a}}$ & $5.13^{\mathrm{a}}$ & $2.16^{\mathrm{a}}$ & $1.71^{\mathrm{a}}$ & $2.97^{\mathrm{a}}$ & $3.71^{\mathrm{a}}$ & $3.38^{\mathrm{a}}$ & 20 & 1.88 & $>0.05$ & II \\
\hline & $5-20$ & $0.10^{\mathrm{c}}$ & $4.33^{\mathrm{a}}$ & $1.62^{\mathrm{bc}}$ & $0.87^{\mathrm{c}}$ & $2.78^{\mathrm{b}}$ & $1.89^{\mathrm{bc}}$ & $0.90^{\mathrm{c}}$ & 20 & 11.93 & $<0.001$ & I \\
\hline
\end{tabular}

Note: SOC, TN, TP, and EC represent soil organic carbon, total nitrogen, total phosphorus and electrical conductivity, respectively; numbers in row followed by the same letters are not significantly different $(P>0.05)$.

2.1.3 Relationships between the soil physical and chemical properties

The relationships of silt+clay content with the SOC, TN and available P content were shown in Fig. 8 . At $0-5 \mathrm{~cm}$ depth, except for the soil available $\mathrm{P}$ content in the alley, the SOC, TN, and available P content were all positively correlated with the silt + clay content $(P<0.01)$ (Figs. 8a, c, e, g, i). At 5-20 cm depth, the SOC and TN (under canopy) contents also exhibited positive relationships with the soil silt+clay content $(P<0.05)$ (Figs. 8b, d, f).

\subsection{Soil susceptibility to wind erosion}

The EF values of all the ages, except at age 0, were less than $40 \%$; and the values significantly decreased with increasing plantation ages in the corresponding locations and depths (Figs. 9a-d). The mean EF values of $0-39$ years showed that the EF values decreased from $39.7 \%$ to $23.38 \%$ under canopy at $0-5 \mathrm{~cm}$, from $37.7 \%$ to $25.4 \%$ under canopy at $5-20 \mathrm{~cm}$, from $39.7 \%$ to $24.3 \%$ in the alley at $0-5 \mathrm{~cm}$ and from $37.7 \%$ to $26.5 \%$ in the alley at $5-20 \mathrm{~cm}$.

\subsection{Variation of herbaceous traits}

With the increase of the plantation ages, the original shift sand dunes were gradually stabilized and the total herbaceous cover and the total number of individuals increased (Table 3). The species composition had less statistical fluctuation in response to the improved soil environment and a maximum species number of 4 occurred in the $13^{\text {th }}$ - and $16^{\text {th }}$-year. Notably, compared with plantation in 5-, 9-, 13-, 16-, 31-, and 39-year, Agriophyllum squarrosum occupied the dominant position before 2 years plantation, but it was replaced by Bassia dasyphylla after 2 years plantation with the maximum proportion increased to $100 \%$. 

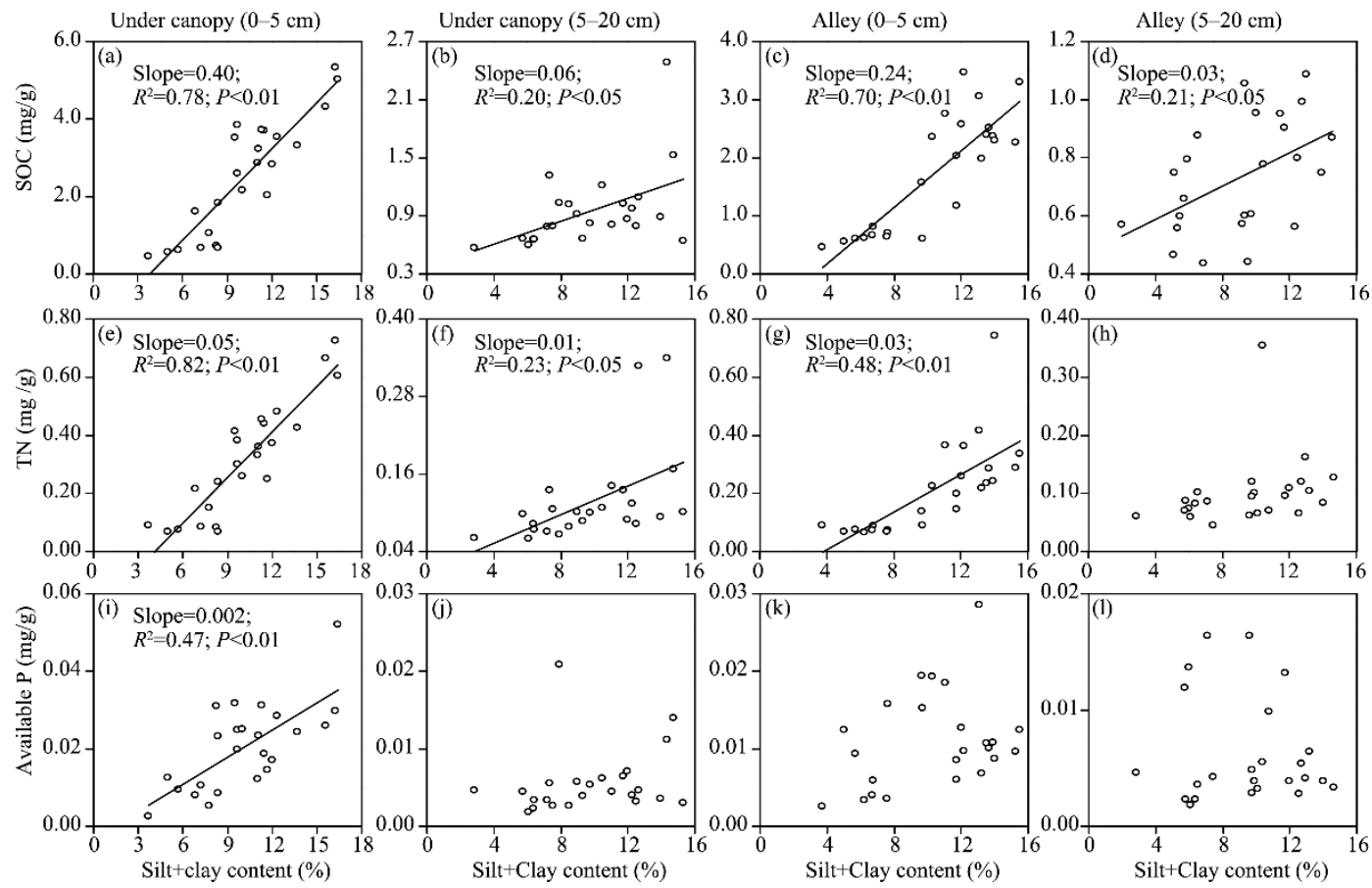

Fig. 8 Linear regression relationships of SOC, TN and available $\mathrm{P}$ at different locations and depths along the plantation age sequence

Table 3 Characteristics of herbaceous species along the age sequence

\begin{tabular}{|c|c|c|c|c|c|c|}
\hline \multirow{2}{*}{ Plantation ages (year) } & & \multicolumn{4}{|c|}{ Species name } & \multirow{2}{*}{$\mathrm{Cr}(\%)$} \\
\hline & & $B d$ & As & $\mathrm{Ha}$ & $\mathrm{Sr}$ & \\
\hline \multirow{3}{*}{0} & Number & 10 & 51 & 1 & - & 3 \\
\hline & Height $(\mathrm{cm})$ & 4.6 & 6.9 & 11.0 & - & - \\
\hline & $\mathrm{P}(\%)$ & 16 & 82 & 2 & - & - \\
\hline \multirow{3}{*}{2} & Number & 19 & 52 & 13 & - & 5 \\
\hline & Height $(\mathrm{cm})$ & 3.0 & 4.2 & 2.4 & - & - \\
\hline & $\mathrm{P}(\%)$ & 23 & 62 & 15 & - & - \\
\hline \multirow{3}{*}{5} & Number & 103 & - & - & - & 8 \\
\hline & Height $(\mathrm{cm})$ & 6.6 & - & - & - & - \\
\hline & $\mathrm{P}(\%)$ & 100 & - & - & - & - \\
\hline \multirow{3}{*}{9} & Number & 124 & 2 & - & - & 8 \\
\hline & Height $(\mathrm{cm})$ & 7.2 & 7.1 & - & - & - \\
\hline & $\mathrm{P}(\%)$ & 99 & 1 & - & - & - \\
\hline \multirow{3}{*}{13} & Number & 214 & 3 & 2 & 3 & 9 \\
\hline & Height $(\mathrm{cm})$ & 6.4 & 4.0 & 6.4 & 5.3 & - \\
\hline & $\mathrm{P}(\%)$ & 96 & 1 & 1 & 2 & 9 \\
\hline \multirow{3}{*}{16} & Number & 223 & 1 & 9 & 2 & - \\
\hline & Height $(\mathrm{cm})$ & 7.0 & 2.0 & 8.8 & 3.0 & - \\
\hline & $\mathrm{P}(\%)$ & 95 & 0 & 4 & 1 & - \\
\hline \multirow{3}{*}{31} & Number & 256 & 11 & 7 & - & 11 \\
\hline & Height $(\mathrm{cm})$ & 7.0 & 8.6 & 8.1 & - & - \\
\hline & $\mathrm{P}(\%)$ & 93 & 4 & 3 & - & - \\
\hline \multirow{3}{*}{39} & Number & 263 & 17 & 2 & - & 11 \\
\hline & Height $(\mathrm{cm})$ & 4.3 & 6.8 & 2.8 & - & - \\
\hline & P (\%) & 93 & 6 & 1 & - & - \\
\hline
\end{tabular}

Note: Bd, Bassia dasyphylla; As, Agriophyllum squarrosum; Ha, Halogeton arachnoideus; Sr, Salsola ruthenica; Cr, coverage; $\mathrm{p}$, number of each individual /total number of individuals 

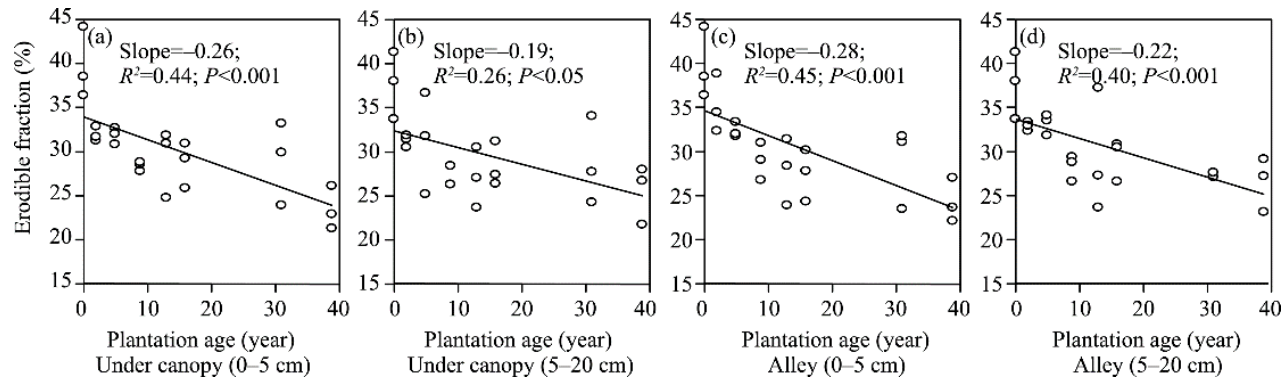

Fig. 9 Variation of Erodible fraction (EF) values at different locations and depths along the plantation age sequence

\section{Discussion}

\subsection{The changes of soil characteristics}

A number of studies suggested that the presence of shrubs dramatically influences and alters the spatial distribution of the soil physical-chemical properties (Schlesinger et al., 1996; Wezel et al., 2000; Xie and Steinberger, 2001). The present study also showed that planting H. ammodendron on shifting sand dunes resulted in significant improvements in the soil physical and chemical properties. Meanwhile, these positive effects increased with the increase of the plantation ages. These results are in line with previous studyies conducted in the Shapotou area, northwestern China and in the Horqin Sandy Land, northern China (Su and Zhao, 2003; Li et al., 2007).

In this study, planting $H$. ammodendron significantly decreased the sand contents under canopy and in the alley and increased the silt, clay, SOC, TN and TP contents, with the exception of TP in the alley. One of the most important factors facilitating these improvements in soil properties is that, as natural barriers for reducing wind velocity, the plantation of $H$. ammodendron in the oasisdesert ecotone leads to an enrichment of wind-blown fine materials through stem flow and through fall (Wezel et al., 2000). Such accumulations contribute to continuous increases in the silt and clay contents in the topsoil with increasing plantation age. Meanwhile, the positive correlations of the soil silt+clay content with the soil chemical properties show that the increased amount of fine-size particles results in an improvement in the SOC and TN (von Lützow M et al., 2008; Schleuß et al., 2014). Furthermore, the increased SOC plays an important role in the plant colonization and establishment since it acts as a reservoir for essential elements, particularly TN and TP (Li et al., 2007). In addition, the biological inputs of $\mathrm{N}$ fixation and the accumulation of atmospheric $\mathrm{N}$ deposition over time could contribute to the increase of soil $\mathrm{N}$ (Jiao et al., 2013). The rate of nutrient accumulation at $0-5 \mathrm{~cm}$ depth was greater than that at 5-20 $\mathrm{cm}$ depth, demonstrating that the soil formation was slower in the deeper layers than in the topsoil.

Compared with the $\mathrm{C}: \mathrm{P}$ and $\mathrm{N}: \mathrm{P}$ ratios, the $\mathrm{C}: \mathrm{N}$ ratios showed constant trend with increasing plantation age. On the one hand, it indicates that variation of the soil $\mathrm{C}$ content synchronized with the soil $\mathrm{N}$ content; on the other hand, it exhibits a stronger coupling between the $\mathrm{C}$ and $\mathrm{N}$ cycle than the $\mathrm{C}$ and $\mathrm{P}$ or the $\mathrm{N}$ and $\mathrm{P}$ cycles (Tian et al., 2010; Jiao et al., 2013). Also, the soil P presented a narrow variation among plantation ages; however, it has important influences on the variation of the $\mathrm{C}: \mathrm{P}$ and $\mathrm{N}: \mathrm{P}$ ratios, suggesting that the $\mathrm{C}: \mathrm{N}: \mathrm{P}$ ratio in the soil is mainly controlled by the $\mathrm{P}$ supply (Tian et al., 2010).

Although soil $\mathrm{pH}$ showed an increasing trend with increasing plantation age, there was no significant difference among the different plantation ages. This was in disaccorded with a previous study that the extensive secretion of organic acids and the release of $\mathrm{CO}_{2}$ from the roots and/or microorganisms lead to a decreased $\mathrm{pH}$ with increasing vegetation cover ( $\mathrm{Su}$ and $\mathrm{Zhao}, 2003$ ). Herein, we provide the following reason to explain the higher $\mathrm{pH}$ value in the present study. $H$. ammodendron mainly absorbs soil $\mathrm{NO}_{3}{ }^{-}$and that one $\mathrm{OH}^{-}$is released when one $\mathrm{NO}_{3}{ }^{-}$ion is absorbed, which, in turn, influences the soil $\mathrm{pH}$ (James et al., 2005). In the present study, the increased EC, ranging from 115.4 to $1,996.17 \mu \mathrm{s} / \mathrm{cm}$, indicates increasing soil salinity. It is in 
agreement with the conclusion that $H$. ammodendron lands without irrigation have a significant salt accumulation, especially in the topsoil ( $\mathrm{Su}$ et al., 2007). Based on this, we also examined the variation in the soil $\mathrm{CaCO}_{3}$ and the available $\mathrm{P}$ contents since $\mathrm{CaCO}_{3}$ is an important component of salinity and it fixes the soil available $\mathrm{P}$, leading to a decrease in the available $\mathrm{P}$ content (Hinsinger, 2001). However, the result exceeded all expectations. Although the $\mathrm{CaCO}_{3}$ content showed an increasing trend with increasing plantation age, there were no significant difference among plantation ages. Meanwhile, the available $\mathrm{P}$ content only presented a pronounced difference at $0-5$ $\mathrm{cm}$ depth under the canopy. Moreover, the ratio of $\mathrm{CaCO}_{3}$ : available $\mathrm{P}$ only exhibited a significant decreasing trend at $0-5 \mathrm{~cm}$ depth under the canopy, which was caused by increasing available $\mathrm{P}$ content. This result only indicates that the variation of $\mathrm{CaCO}_{3}$ does not pose a threat to the increase of available $\mathrm{P}$ at $0-5 \mathrm{~cm}$ depth under the canopy. Thus, further studies are needed to identify other factors that could directly and/or indirectly be responsible for the age-related variation in the soil $\mathrm{P}$ availability and the influence of soil available $\mathrm{P}$ on plant uptake.

\subsection{Time effects of the soil environment recovery}

According to the accumulation of SOC and TN, we concluded that there were two distinct phases after H. ammodendron was planted: a faster soil environment recovery rate during the early plantation stage (0-9 years) and a slower recovery rate during the late successional stage (9-39 years) (Fig. 7). In addition, the recovery rates under the canopy are faster than those in the alley over the both stages (Fig. 7). Similar recovery patterns were observed in other studies which examined the restoration effects of tree plantations on degraded soils (Singh et al., 2001; Su and Zhao, 2003).

In arid and semi-arid desert ecosystems, the shrub canopy and alley may be subject to different degrees and redistribution of erosion, deposition and litter inputs (Hook et al., 1991). Normally, it is called "fertility of islands that the nutrition content under the canopy are higher than that in the alley". To some extent, this can alter the soil water and nutrition contents, which play an important role in the structure, production, and dynamics of the vegetation in arid ecosystems (Aguiar and Sala, 1999; Li et al., 2011). The enrichment ratios (E) of the soil properties in the present study were greater than 1 and verified the effect of "fertile island" under canopy. However, the E values among different ages were not significantly different, suggesting that the soil properties had a more uniform distribution under the canopy and in the alley.

Soil wind erosion is a widespread cause of serious soil degradation in arid and semi-arid regions (Singh et al., 1999; Li et al., 2004a; Borrelli et al., 2014). Thus, soil erodibility, defined as the susceptibility of soil particles to detachment and transportation by wind, was used as an essential parameter for examining soil wind erosion (Bryan, 1968; Geeves et al., 2000; Zhou et al., 2015). López (2007) proposed three erodibility classifications by the erodible fraction (EF) value: higher than 50\% (high erodibility), between $40 \%$ and $50 \%$ (moderate erodibility), and less than $40 \%$ (slight erodibility). The mean EF value of the non-vegetated soil in the present study was $39.70 \%$, which was not significantly different from $40 \%(P>0.05)$, indicating that the sand dunes approached a moderate erodiblity. Further, the EF value decreased significantly after $\mathrm{H}$. ammodendron was planted, denoting that the study area had transformed from moderate erodibility to slight erodibility. Obviously, this effect was reinforced with increasing plantation ages.

\subsection{Restoration effects on herbaceous species}

Previous studies showed that the accumulation of SOC and TN with increasing plantation ages could form an important safeguard against soil erosion and can further contribute to growth conditions that are favorable for vegetation recovery and growth, especially for herbaceous species (Ffolliott et al., 1995; Li et al., 2004b). In the present study, though the total number of herbaceous individuals clearly increased, herbaceous species composition did not increase dramatically. Moreover, the proportion of dominant species (Bassia dasyphylla) increased by nearly $100 \%$ after 5 years of planting, but the proportion of Agriophyllum squarrosum gradually declined. These data reflect that the increased soil salinity led to the recession of Agriophyllum squarrosum and the occupation of extremely salt-tolerant annual herbaceous species. In addition, the restoration of the 
soil properties did not facilitate the recovery of the herbaceous species. Therefore, whether soil restoration in the oasis-desert ecotone improves vegetation recovery still requires careful consideration.

\section{Conclusions}

Comprehensively, the above results not only verified that the plantation of shrub vegetation is the trigger spot for the restoration of vegetation in an arid ecosystem but also demonstrated that the plantation of $H$. ammodendron plays a vital role in the restoration of a desertified ecosystem in the oasis-desert region of northern China. Moreover, our findings enrich the study of $H$. ammodendron in soil restoration. However, the formation and development of soil is a complicated and slow process; thus, long-term monitoring is critically important to evaluate whether soil recovery in this region can occur and to provide more knowledge about the restoration effect of $H$. ammodendron in an arid environment and the maintenance of sustainable development under water limited conditions.

\section{Acknowledgements}

This research was funded by the National Natural Science Foundation of China (41401337).

\section{References}

Aguiar M R, Sala O E. 1999. Patch structure, dynamics and implications for the functioning of arid ecosystems. Trends in Ecology \& Evolution, 14(7): 273-277.

Bao S D. 2000. Soil and Agricultural Chemistry Analysis (3 ${ }^{\text {rd }}$ ed.). Beijing: China Agricultural Press. (in Chinese)

Borrelli P, Ballabio C, Panagos P, et al. 2014. Wind erosion susceptibility of European soils. Geoderma, s 232-234(12): 471-478.

Bryan R B. 1968. The development, use and efficiency of indices of soil erodibility. Geoderma, 2(1): 5-26.

Chen L H, Li F X, Di X M, et al. 1998. Aeolian Sandy Soils in China. Beijing: Science Press. (in Chinese)

Ffolliott P F, Gottfried G J, Rietveld W J. 1995. Dryland forestry for sustainable development. Journal of Arid Environments, 30(2): 143-152.

Fryrear D W, Krammes C A, Williamson D L, et al. 1994. Computing the wind erodible fraction of soils. Journal of Soil and Water Conservation, 49(2): 183-188.

GB 7857-1987. 1988. Determination of Organic Matter in Forest Soil and Calculation of Carbon-Nitrogen Ratio. Beijing: Standardization Administration of the People's Republic of China, 166-167. (in Chinese)

Gee G W, Bauder J W. 1986. Particle-size analysis. In: Klute A. Methods of Soil Analysis. Part 1. Physical and Mineralogical Methods ( $2^{\text {nd }}$ ed.). Madison: Soil Science Society of America, 383-411.

Geeves G W, Leys J F, McTainsh G H. 2000. Soil erodibility. In: Charman P E V, Murphy B W. Soils: Their Properties and Management. New York: Oxford University Press, 205-220.

Han D L. 1999. The progress of research on oasis in China. Scientia Geographica Sinica, 19(4): 313-319. (in Chinese)

He Z B, Zhao W Z. 2004. The spatial heterogeneity of soil moisture in artificial Haloxylon ammodendron. Journal of Glaciology and Geocryology, 26(2): 207-211. (in Chinese)

Hinsinger P. 2001. Bioavailability of soil inorganic P in the rhizosphere as affected by root-induced chemical changes: a review. Plant and Soil, 237(2): 173-195.

Hook P B, Burke I C, Lauenroth W K. 1991. Heterogeneity of soil and plant N and C associated with individual plants and openings in North American shortgrass steppe. Plant and Soil, 138(2): 247-256.

James J J, Tiller R L, Richards J H. 2005. Multiple resources limit plant growth and function in a saline-alkaline desert community. Journal of Ecology, 93(1): 113-126.

Jiao F, Wen Z M, An S S, et al. 2013. Successional changes in soil stoichiometry after land abandonment in Loess Plateau, China. Ecological Engineering, 58: 249-254.

Li C J, Li Y, Ma J. 2011. Spatial heterogeneity of soil chemical properties at fine scales induced by Haloxylon ammodendron (Chenopodiaceae) plants in a sandy desert. Ecological Research, 26(2): 385-394.

Li F R, Zhao L Y, Zhang H, et al. 2004. Wind erosion and airborne dust deposition in farmland during spring in the Horqin Sandy Land of eastern Inner Mongolia, China. Soil and Tillage Research, 75(2): 121-130.

Li X R, Zhang Z S, Zhang J G, et al. 2004. Association between vegetation patterns and soil properties in the southeastern Tengger 
Desert, China. Arid Land Research and Management, 18(4): 369-383.

Li X R, Kong D S, Tan H J, et al. 2007. Changes in soil and vegetation following stabilisation of dunes in the southeastern fringe of the Tengger Desert, China. Plant and Soil, 300(1-2): 221-231.

López M V, de Dios Herrero J M, Hevia G G, et al. 2007. Determination of the wind-erodible fraction of soils using different methodologies. Geoderma, 139(3-4): 407-411.

Pan X L. 2001. A preliminary study on the stability of oasis ecosystem in arid area. Quaternary Sciences, 21(4): 345-351. (in Chinese)

Pan X L, Chao J P. 2003. Theory of stability, and regulation and control of ecological system in oasis. Global and Planetary Change, 37(3-4): 287-295.

Schlesinger W H, Raikes J A, Hartley A E, et al. 1996. On the spatial pattern of soil nutrients in desert ecosystems. Ecology, 77(2): 364-374.

Schleuß P M, Heitkamp F, Leuschner C, et al. 2014. Higher subsoil carbon storage in species-rich than speices-poor temperate forests. Environmental Research Letters, 9(1): 014007.

Singh K P, Mandal T N, Tripathi S K. 2001. Patterns of restoration of soil physciochemical properties and microbial biomass in different landslide sites in the sal forest ecosystem of Nepal Himalaya. Ecological Engineering, 17(4): 385-401.

Singh U B, Gregory J M, Wilson G R. 1999. Texas erosion analysis model: theory and validation. In: Skidmore E L, Tatarko J. Wind Erosion Proceedings of an International Symposium/Workshop. Manhattan: United States Department of Agriculture (USDA), Agricultural Research Service, Wind Erosion Research Unit.

Su P X, Cheng G D, Yan Q D, et al. 2007. Photosynthetic regulation of C4 desert plant Haloxylon ammodendron under drought stress. Plant Growth Regulation, 51(2): 139-147.

Su Y Z, Zhao H L, Wen H Y. 2002. Cultivation and enclosure effects on soil physicochemical properties of degraded sandy grassland. Journal of Soil and Water Conservation, 16(4): 5-8, 126. (in Chinese)

Su Y Z, Zhao H L. 2003. Soil properties and plant species in an age sequence of Caragana microphylla plantations in the Horqin Sandy Land, north China. Ecological Engineering, 20(3): 223-235.

Su Y Z, Zhao W Z, Su P X, et al. 2007. Ecological effects of desertification control and desertified land reclamation in an oasisdesert ecotone in an arid region: A case study in Hexi Corridor, northwest China. Ecological Engineering, 29(2): 117-124.

Su Y Z, Wang X F, Yang R, et al. 2010. Effects of sandy desertified land rehabilitation on soil carbon sequestration and aggregation in an arid region in China. Journal of Environmental Management, 91(11): 2109-2116.

Su Y Z, Wang X F, Yang R, et al. 2012. Soil fertility, salinity and nematode diversity influenced by Tamarix ramosissima in different habitats in an arid desert oasis. Environmental Management, 50(2): 226-236.

Tian H Q, Chen G S, Zhang C, et al. 2010. Pattern and variaition of C:N:P ratios in China's soils: A synthesis of observational data. Biogeochemistry, 98(1-3): 139-151.

von Lützow M, Kögel-Knabner I, Ludwig B, et al. 2008. Stabilization mechanisms of organic matter in four temperate soils: Development and application of a conceptual model. Journal of Plant Nutrition and Soil Science, 171(1): 111-124.

Wezel A, Rajot J L, Herbrig C. 2000. Influence of shrubs on soil characteristics and their function in Sahelian agro-ecosystems in semi-arid Niger. Journal of Arid Environments, 44(4): 383-398.

Xie G H, Steinberger Y. 2001. Temporal patterns of C and N under shrub canopy in a loessial soil desert ecosystem. Soil Biology and Biochemistry, 33(10): 1371-1379.

Zhao H L, Zhou R L, Su Y Z, et al. 2007. Shrub facilitation of desert land restoration in the Horqin Sand Land of Inner Mongolia. Ecological Engineering, 31(1): 1-8.

Zhao W Z, Hu G L, Zhang Z H, et al. 2008. Shielding effect of oasis-protection systems composed of various forms of wind break on sand fixation in an arid region: A case study in the Hexi Corridor, northwest China. Ecological Engineering, 33(2): $119-125$.

Zhou Y, Guo B, Wang S X, et al. 2015. An estimation method of soil wind erosion in Inner Mongolia of China based on geographic information system and remote sensing. Journal of Arid Land, 7(3): 304-317.

Zhu Y J, Jia Z Q. 2011. Soil water utilization characteristics of Haloxylon ammodendron plantation with different age during summer. Acta Ecologica Sinica, 31(6): 341-346. 